\begin{tabular}{l}
\hline MATAPPA: Jurnal Pengabdian Kepada Masyarakat \\
Volume $2 \mid$ Nomor $2 \mid$ September |2019 \\
e-ISSN: 2614-6673 dan p-ISSN: $2615-5273$ \\
\begin{tabular}{|l|l|} 
(c) (1) This work is licensed under a Creative Commons Attribution \\
\hline
\end{tabular}
\end{tabular}

PKM Kelompok Guru Bidang Studi Biologi Kota Palopo Untuk Meningkatkan Keterampilan Pembuatan Media Pembelajaran

\title{
Saparuddin $^{1}$, Charmilasari ${ }^{2}$ Akhmad Syakur ${ }^{1}$
}

Keywords :
Kelompok Guru Biologi,
Media Pembelajaran
Keywords: biology teacher
group, learning media
Corespondensi Author
${ }^{1}$ Pendidikan Biologi, Universitas
Cokroaminoto Palopo
Perumahan Banawa, Kota
Palopo
Email: Saparuddinappi@gmail.com

History Artikel

Received: 24-08-2019;

Reviewed: 25-08-2019;

Revised: 13-09-2019;

Accepted: 16-09-2019;

Published: 29-09-2019

\begin{abstract}
Abstrak. Kegiatan ini bertujuan untuk mengatasi permaslahan mitra dalam hal ini guru biologi di tingkat SMA se Kota Palopo terkait dengan media pembelajaran biologi, yaitu; 1) Terbatasnya media pembelajaran biologi di sekolah, 2) Ketergantungan guru pada media pembelajaran yang sudah tersedia di internet, 3) Kurangnya kegiatan pelatihan pembuatan media pembelajaran, 4) Keterampilan guru dalam membuat media pembelajaran, 5) Referensi tentang media pembelajaran biologi. Solusi dari beberapa permasalahan mitra adalah 1) Pelatihan pembuatan media pembelajaran Biologi, 2) Pendampingan pembuatan media 3) Menyediakan sumber referensi bagi guru terkait. Kegiatan pelatihan dilakukan sebanyak tiga sesi, masing-masing sesi dilaksanakan selama tiga hari. Adapun jenis pelatihan pada masing-masing sesi adalah; 1) pelatihan pembuatan media berbasis IT, 2) pelatihan pembuatan media berbasis elearning, 3) pelatihan pembuatan alat peraga. Kegiatan pendampingan dilakukan di tiga sekolah, yaitu; SMA Negeri 1 Palopo, SMA Negeri 2 Palopo dan SMA Negeri 4 Palopo. Hasil dari kegiatan PKM menunjukkan bahwa guru-guru sangat antusias dan berpartisipasi serta memiliki keinginan yang kuat untuk tetap melanjutkan program-program yang sangat bermanfaat bagi mereka, seperti pembuatan media pembelajaran berupa awetan, multimedia, dan e-learning. Pemahaman dan keterampilan yang mereka peroleh dilaksanakn dan diterapkan di sekolah masing-masing.
\end{abstract}


are; SMA Negeri 1 Palopo, SMA Negeri 2 Palopo and SMA

Negeri 4 Palopo. The results of thiscommunity services show that teachers are very enthusiastic and directly participate this training. Moreover, they have a strong desire to continue programs that are very beneficial to them, such as making learning media in the form of preservation, multimedia, and $e$ learning. Their understanding and skills are carried out and applied in their respective schools.

\section{PENDAHULUAN}

Pendidikan merupakan suatu kekuatan yang dinamis dalam kehidupan setiap individu, yang mempengaruhi perkembangan fisik, dan perkembangan jiwa, perkembangan sosial, dan perkembangan moralitasnya. Pendidikan dapat dikatakan sebagai suatu proses perubahan sikap dan tingkah laku seseorang atau kelompok orang dalam usaha mendewasakan manusia melalui usaha pengajaran dan pelatihan. Menurut Islamuddin (2012), pendidikan dalam arti luas dapat diartikan sebuah proses dengan metodemetode tertentu sehingga individu memperoleh pengetahuan, pemahaman dan cara bertingkah laku yang sesuai dengan kebutuhan.

Santayasa (2007) mengungkapkan bahwa banyak faktor yang mempengaruhi pencapaian hasil belajar siswa, salah satunya yaitu media pembelajaran yang digunakan selama proses belajar mengajar. Sejalan dengan berkembangnya teknologi dan formasi yang ada, maka dalam proses pembelajaran juga diperlukan adanya suatu bentuk media pembelajaran dalam menyampaikan suatu informasi kepada peserta didik.

Media pembelajaran merupakan bagian penting dalam pelaksanaan pendidikan di sekolah. Melalui media pembelajaran guru akan lebih mudah dalam menyampaikan materi dan siswa akan lebih terbantu dan mudah belajar. Media pembelajaran adalah perantara yang membawa pesan atau informasi antara sumber dan penerima (Depdiknas, 2006)

Media pembelajaran yang tepat dan layak dalam kegiatan pembelajaran, diharapkan dapat membantu guru menyampaikan materi pembelajarannya dengan lebih jelas dan mudah dipahami serta dapat diterima dengan baik oleh peserta didik sehingga tercapai tujuan pembelajaran yang sudah ditetapkan. Selain itu, pemakaian media pembelajaran dalam proses belajar mengajar akan membangkitkan motivasi dan minat siswa terhadap materi yang disampaikan sehingga timbul rasa ingin tahu yang mendorong siswa untuk belajar (Saparuddin dan Ekawati, 2017).

Saat ini, perkembangan media cetak, media elektronik, teknologi informasi dan komunikasi sebagai sumber belajar atau sumber informasi sangat melimpah. Setiap peserta didik dapat mengakses berbagai informasi yang terkait dengan materi pembelajaran di sekolah dari berbagai media yang ada dengan sangat mudah. Posisi guru pun tidak lagi menjadi satu-satunya sumber belajar. Guru harus mampu memerankan diri sebagai fasilitator bagi siswa, khususnya dalam pemanfaatan berbagai sumber belajar baik yang tersedia di sekolah atau di luar sekolah. Guru harus memiliki wawasan pengetahuan yang luas, mengenal teknologi, dan kreatif memanfaatkan situasi lingkungan alam dan sosial untuk dijadikan sebagai sumber belajar ataupun media pembelajaran di samping bahan-bahan pustaka.

Berdasarkan hasil penelitian yang dilakukan oleh ketua tim pengusul pada tahun 2017 tentang observasi penggunaan media pembelajaran oleh guru biologi pada tingkat SMA se Kota Palopo (Saparuddin dan Ekawati, 2017) ditemukan bahwa umumnya para guru telah menyadari pentingnya penggunaan media di dalam proses pembelajaran, hal ini dapat diketahui melalui respons positif pada lima jenis media yang dijadikan sebagai fokus penelitian. Respons positif diartikan bahwa kelima jenis media tersebut pernah digunakan guru dalam proses pembelajaran, hanya saja jika respons dari para responden dimasukkan ke dalam tabel kategori, penggunaan media pembelajaran biologi di sekolah masih berada pada kategori sedang. Hal ini mengindikasikan terdapat permasalahan-permasalahan terkait dengan 


\section{MATAPPA: Jurnal Pengabdian Kepada Masyarakat.}

penggunaan media pembelajaran pada mata pelajaran Biologi di sekolah.

Tim pengusul telah melakukan wawancara dengan ketua MGMP Biologi Kota Palopo dan merumuskan permasalahan guru biologi di sekolah terkait dengan media pembelajaran sebagai berikut: (a) Terbatasnya jenis media pembelajaran biologi yang tersedia di sekolah; (b) Ketergantungan guru pada media pembelajaran yang sudah tersedia di internet; (c) Kurangnya kegiatan pelatihan/ workshop/ lokakarya pembuatan media pembelajaran; (d) Keterampilan guru dalam membuat media pembelajaran; (e) Referensi tentang ragam media pembelajaran biologi

Berdasarkan permasalahan mitra, tim pengusul melaksana tiga kegiatan yang diharapkan dapat menjadi solusi bagi mitra, yaitu: (1) Pelatihan pembuatan media pembelajaran biologi; (2) Pendampingan pembuatan media pembelajaran biologi; (3) Menyediakan sumber referensi bagi guru terkait ragam media pembelajaran biologi dan tata cara pembuatannya.

Pelaksanaan kegiatan pelatihan terdiri dari tiga sesi, yaitu pelatihan pembuatan media berbsis IT, media e-learning dan alat peraga pembelajaran biologi.

Media berbasis IT yang dilatihkan diantaranya adalah media presentasi Powtoon dan instrumen evaluasi berbasis Kahoot. Media presentasi Powtoon memiliki tampilan yang menarik dibandingkan media presentasi biasa karena menggunakan fitur kartun yang dapat bergerak dan pembuatannya juga cukup mudah. Berdasarkan hasil penelitian Pangestu dan Achmad (2018) disimpulkan bahwa media interaktif powtoon yang dikembangkan dapat digunakan di dalam pembelajaran dengan ratarata nilai validasi mencapai $90,57 \%$.

Instrumen evaluasi berbasis Kahoot yang dimaksudkan dalam kegiatan ini adalah alat evaluasi yang dikembangkan dalam bentuk kuis dengan menggunakan aplikasi Kahoot dan dapat diakses oleh siswa menggunakan laptop maupun gadget. Media ini memungkinkan guru melakukan evaluasi terhadap proses pembelajaran lebih mudah dan penilaian yang transparan serta menyenangkan bagi siswa karena dapat melihat langsung nilai dan mengoreksi jawabannya. Menurut Rofiyanti dan Anisa (2017) Desain permainan dalam Kahoot yang bersifat multiplayer memungkinkan anak untuk dapat berkolaborasi sekaligus berkompetisi melalui permainan yang interaktif. Aktivitas yang dilakukan dengan menggunakan platform ini dapat memfasilitasi interaksi sosial anak sehingga kecenderungan terjadinya kecanduanterhadap teknologi (gadget addict) dapat dikurangi.

Salah satu media e-learning yang dilatihkan dalam kegiatan ini adalah berbasis edmodo. Melalui media ini guru akan lebih mudah mengontrol siswa dalam kegiatan pembelajaran. Media ini memiliki tampilan yang menarik serta cara akses yang mudah bagi siswa. Berdasarkan hasil penelitian yang dilakukan oleh Rulviana (2018) disimpulkan pembelajaran menggunakan edmodo sangat membantu bagi dosen maupun mahasiswa. Kelancaran proses belajar mengajar didapat lewat fitur tersebut. Jarak, waktu, maupun tempat tidak lagi menjadi penghalang terlaksananya proses pembelajaran dengan adanya aplikasi tersebut.

Alat peraga merupakan media pengajaran yang mengandung atau membawakan ciri-ciri dari konsep yang dipelajari (Estiningsih, 1994). Alat peraga pembelajaran biologi yang akan dilatihkan pada kegiatan ini diantaranya herbarium, insektarium, model/torso, taksdermi dan alat peraga portable. Alat peraga masih dibutuhakan dalam pembelajaran biologi di era digital saat ini. Alat peraga dapat memberikan penggambaran yang lebih nyata terhadap objek maupun materi yang sedang dipelajari. Hasil penelitian Saleh, dkk (2015) mengungkap bahwa terdapat pengaruh pengguanaan alat peraga di dalam pembelajaran terhadap hasil belajar siswa

\section{METODE}

Solusi yang telah dirumuskan oleh tim pengusul untuk mengatasi permasalahan guru biologi di Kota Palopo sebagai mitra akan dilaksanakan dengan mengacu pada rancangan kegiatan sebagai berikut:

\section{Persiapan}

Kegiatan-kegiatan yang dilakukan pada tahap persiapan sebagai berikut:

a. Survei tempat pelaksanaan kegiatan. Mitra dalam kegiatan ini adalah semua guru biologi Kota Palopo yang tergabung dalam kelompok Musywarah Guru Mata Pelajaran (MGMP) Biologi. Berdasarakan hasil wawancara dengan ketua MGMP Biologi Kota Palopo, disebutkan bahwa umunya kegiatan-kegiatan organisasi yang dipimpinnya dilakukan di SMAN 3 Palopo, sehingga kegiatan PKM ini nantinya akan di fokuskan di SMAN 3 Palopo. 
b. Sosialisasi, pada kegiatan ini tim pengusul akan melakukan sosialisasi kepada guru biologi Kota Palopo yang tersebar di 15 (lima belas) sekolah (6 SMA Negeri dan 9 SMA Swasta). Sosialisasi bertujuan untuk menyampaikan jenis kegaiatan yang akan dilaksanakan kepada mitra.

c. Analisis dan menyiapkan kebutuhan kegiatan PKM, analisis kebutuhan untuk mengidentifikasi dan menyiapkan hal-hal yang dibutuhkan dalam kegiatan ini, seperti; tempat pelaksanaan, alat dan bahan pembuatan media, narasumber, dan materi pelatihan.

d. Administrasi, pelibatan guru-guru biologi dalam kegiatan ini akan membutuhkan suatu prosedur yang administratif seperti perijinan dari pihak sekolah tempat mereka mengajar dan rekomendasi kegiatan dari UPT/Dinas terkait.

\section{Pelaksanaan}

PKM ini terdiri atas 3 kegiatan utama, yaitu;

a. Pelatihan pembuatan media pembelajaran biologi

Kegiatan akan dilakukan selama sembilan hari yang terbagi ke dalam tiga sesi. Masingmasing sesi terdiri dari 3 hari. Waktu pelaksanaan setiap sesi berselang satu bulan. Adapun jenis media yang dilatihakan sebagai berikut;

1) Sesi pertama: pelatihan pembuatan media berbasis IT, meliputi media presentasi Prezi, media presentasi Powtoon, evaluasi berbasis Kahoot dan Macromedia flash

2) Sesi kedua: pelatihan pembuatan media elearning diantaranya berbasis edmodo dan google classroom

3) Sesi ketiga: pelatihan pembuatan alat peraga, diantaranya; Herbarium, Insektarium, Taksidermi, Torso/model dan Alat peraga portable

b. Pendampingan pembuatan media pembelajaran biologi

Kegiatan ini merupakan rangkaian kelanjutan dari kegitan pelatihan sebelumnya, hal ini bertujuan untuk mendampingi guru dalam pembuatan media pembelajaran. Pendampingan dilakukan secara intensif, tim pengusul akan mendampingi mitra di sekolah masing-masing dalam pembuatan dan penggunaan media pembelajaran. Kegiatan pendampingan dilakukan minimal tiga kali pada masing-masing sekolah dan juga disesuaikan dengan tingkat kebutuhan dan pemahaman mitra. Sehubungan dengan kondisi mitra yang tersebar di 15 sekolah, agak sulit bagi tim pengusul untuk mengunjungi semua sekolah untuk melakukan pendampingan minimal tiga kali, maka kegiatan pendampingan akan difokuskan pada lima sekolah dengan alasan efesiensi waktu dan dana. Pemilihan lima sekolah sebagai fokus pendampingan mempertimbangkan jumlah guru biologi pada sekolah tersebut, tingkat pemahaman dan kebutuhan guru, dan akan ditentukan melalui kesepakatan bersama setelah proses pelatihan dilaksanakan.

c. Penyusunan Buku tentang ragam media pembelajaran biologi dan cara pembuatannya Buku yang akan disusun berisi tentang ragam media pembelajaran biologi, cara pembutan dan cara penggunaanya dalam proses pembelajaran. Buku yang disusun akan diterbitakan di UNCP Press dan di akhir kegiatan akan dibagikan kepada masing-masing mitra.

\section{Evaluasi}

Evaluasi dilakukan untuk mengetahui tingkat keberhasilan dari kegiatan ini. Kegiatan ini dikatakan berhasil ketika permasalahanpermasalahan yang dikemukakan pada bagian awal telah teratasi. Selain itu, evaluasi juga bertujuan untuk mengetahui kekurangankekurangan dari kegiatan ini yang selanjutnya akan dilkukan perbaikan-perbaikan dengan harapan tujuan dari kegiatan ini dapat tercapai. Kegiatan ini dilakukan dengan dua cara, yaitu:

a. Observasi

Observasi dilakukan kepada mitra ditempat mereka mengajar. Hal yang menjadi objek observasi adalah keterampilan guru dam membuat media, penggunaan media yang variatif di dalam pembelajaran dan penambahan jumlah media pembelajaran biologi di sekolah.

b. Pembagian angket

Angket akan diberikan kepada guru untuk mengetahui respons guru terkait kegiatan yang telah dilaksanakan. Selain itu, siswa juga akan diberikan angket terkait penggunaan media dalam pembelajran biologi. Hal ini bertujuan untuk mendapatkan gambaran ada tidaknya perubahan pengalaman belajar yang dialami siswa sebelum dan sesudah kegiatan.

\section{HASIL DAN PEMBAHASAN}

Kegiatan ini bermitra dengan ketua MGMP Biologi se Kota Palopo. Kegiatan ini berlangsung dengan baik berkat kerjasama dengan mitra serta dukungan penuh dari pihak kampus Universitas Cokroaminoto Palopo. Selain itu, kegiatan ini juga direspons baik oleh Cabang Dinas Pendidikan Wilayah XI Kota Palopo dengan menerbitkan surat rekomendasi 


\section{MATAPPA: Jurnal Pengabdian Kepada Masyarakat.}

kegiatan yang selanjutnya diteruskan kepada kepala UPT SMA se Kota Palopo untuk mengutus guru biologi yang ada pada sekolah tersebut untuk mengikuti kegiatan ini. Hasil yang telah dicapai dari Program Kemitraan Masyarakat ini adalah sebagai berikut:

\section{Pelatihan Pembuatan Media Pembelajaran}

Kegiatan utama dari kegiatan PKM ini adalah pelatihan pembuatan media pembelajaran bagi kelompok guru biologi di Kota Palopo. Kegiatan pelatihan ini dibagi ke dalam tiga sesi, yaitu:

a. Pelatihan pembautan media pembelajaran berbasis IT

Kegiatan ini dilakukan selama tiga hari, yaitu dimulai pada tanggal 21 Juni hingga 23 Juni 2019 di Aula SMA Cokroaminoto Palopo. Kegiatan ini dibuka secara resmi oleh Dekan Fakultas Keguruan dan Ilmu Pendidikan Universitas Cokroaminoto Palopo. Kegiatan ini diikuti 21 guru biologi. Materi yasng dilatihkan pada kegiatan ini adalah tentang media pembelajaran berbasis IT, dan pemateri ataupun instrukur pada masing-masing materi adalah dosen penidikan biologi yang ahli pada materi tersebut, diantaranya; Media Presenatsi Prezi (Saparuddin, S.Pd., M.Pd.), Media presentasi Powtoon (Fitrah Al Anshori, S.Pd., M.Pd.), Instrumen evaluasi berbasis Kahoot (Charmilasari, S.S., M.Hum), Macromedia Flash (Safwan Kasma, S.Kom., M.Pd.). selain pemberian materi, pada kegiatan ini juga memberikan kesempatan kepada guruguru untuk membuat sendiri media pembelajaran melalui kegiatan simulasi dan pendampingan.

b. Pelatihan pembuatan media pembelajaran berbasis e-learning

Kegiatan ini dilaksanakan pada tanggal 18 Juli sampai dengan 21 Juli 2019 di Aula SMA Cokroaminoto Palopo. Pada kegiatan ini, guru dilatihkan cara membuat e-learning serta simulasi cara penggunaanya di dalam pembelajaran.

Adapun jenis e-learning yang dilatihkan kepada guru adalah e-learning berbasis edmodo yang dibawakan oleh Saparuddin, S.Pd., M.Pd. dan Mutmainna Ekawati, S.Pd., M.Pd. materi selanjutnya adalah E-learning berbasis Google Clasroom yang dibawakan oleh Charmilasari, S.Hum., M.Hum dan Eva Sohriati, S.Pd., M.Pd. kegiatan ini diikuti oleh 20 guru biologi.

c. Pelatihan pembuatan alat peraga pembelajaran biologi

Kegiatan ini dilaksanakan pada tanggal 02 Agustus sampai dengan tanggal 04 Agustus 2019. Kegiatan ini diikuti oleh 21 guru biologi.
Adapun materi pada pelatihan ini adalah sebagai berikut; Herbarium (Khaerati, S.Pd., M.Pd.), Taksidermi (Akhmad Syakur, S.Pd., M.Sc), Insektarium (Sukmawati Syam, S.Si., M.Pd.), Torso/Model (Ridha Yulyani Wardi, S.Pd., M.Pd.), Alat Peraga Portable (Saparuddin, S.Pd., M.Pd).

Kegiatan ini direspons baik oleh para peserta, hal ini dapat dilihat dari antusiasme mereka dalam memperhatikan materi yang disampaikan dan aktif dalam kegiatan simulasi pembuatan media secara langsung. Di akhir kegiatan Tim pelaksana meminta kesedian dari peserta untuk menampilkan media pembelajaran yang mereka buat. Hal tersebut menunjukkan terdapat peningkatan keterampilan guru dalam pembuatan media pembelajaran.

Pelatihan pembuatan media pembelajaran sebaiknya dilakukan secara, hal ini sangat membantu guru dalam meningkatkan kemampuan mereka dalam menyiapkan proses pembelajaran yang menarik dan disenangi oleh siswa serta dapat berdampak pada peningkatan kulitas pembelajaran serta hasil belajar pesrta didik. Kegiatan serupa pernah dilakukan oleh Mertha, dkk (2018) yang melakukan pelatihan pembuatan herbarium, pada kegiatan tersebut diungkapkan bahwa Minat dan motivasi yang tinggi dari siswa peserta pelatihan sangat menunjang transfer ilmu pengetahuan dan keterampilan dari dosen kepada peserta pelatihan, sehingga materi pelatihan yang diberikan dapat terserap semua dan produk pembelajaran yang dihasilkan memenuhi kriteria ilmiah. Produk yang dihasilkan dapat dijadikan sebagai perangkat pembelajaran untuk menunjang tercapainya tujuan pembelajaran.

\section{Pendampingan Pembuatan Media Pembelajaran}

Kegiatan pendampingan dilaksanakan setelah kegiatan pelatihan, kegiatan ini dilakukan di tiga sekolah yaitu; SMA Negeri 1 Palopo, SMA Negeri 2 Palopo, dan SMA Negeri 4 Palopo. Adapun kegiatan pendampingan yang telah dilaksanakan adalah pendampingan pembuatan dan penggunaan media berbasis IT di dalam pembelajaran dan pendampingan pembuatan dan penggunaan media berbasis $e$ learning di dalam pembelajaran. Kegiatan ini dilaksanakan masing-masing tiga hari. Pendampingan pembuatan media dilakukan di ruang guru sekolah sedangkan cara penggunaannya langsung di praktekkan di dalam kelas. 
Hasil dari kegiatan ini berupa penguatan kepada guru dalam membuat dan menggunakan media pembelajaran terhadap materi yang telah dilatihkan sebelumnya. Pendampingan yang intensif akan membuat guru lebih mahir dalam membuat media pembelajaran. Kreativitas guru

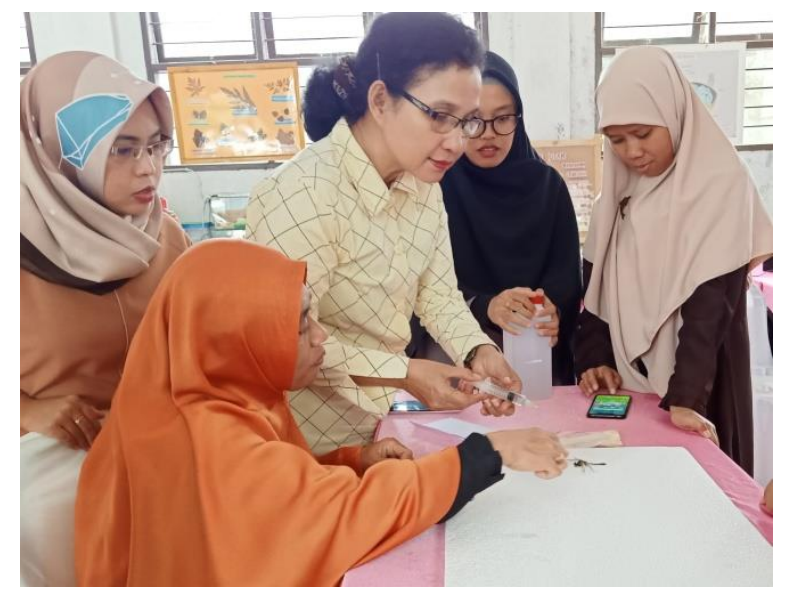

(1)

Gambar: (1) Pelatihan Pembuatan Insektarium

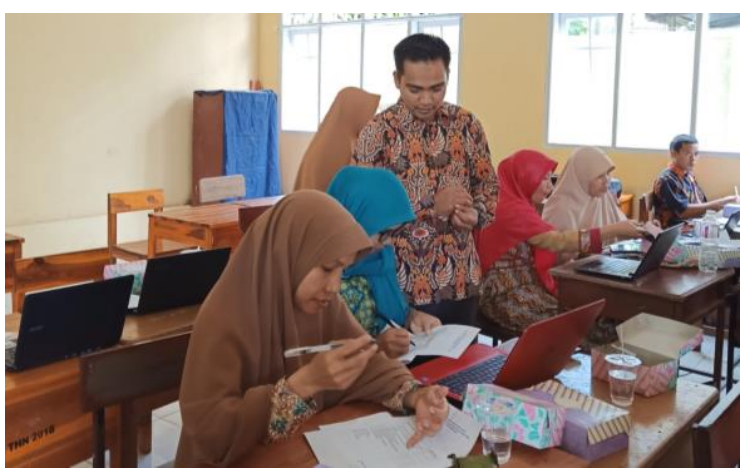

Gabar 3. Kegiatan Pendampingan Pembuatan Media Di Sekolah

\section{SIMPULAN DAN SARAN}

Dari kegiatan yang telah dilaksanakan, maka dapat ditarik kesimpulan yaitu kegiatan Program Kemitraan Masyarakat (PKM) sangat membantu para guru dalam menambah wawasan, pemahaman, keterampilan dalam membuat media pembelajaran dan menggunakannnya dalam proses pembelajaran

\section{DAFTAR RUJUKAN}

Depdiknas. 2006. Kurikulum Satuan Tingkat Pendidikan. Jakarta: Depdiknas.

Estiningsih, Elly. 2014. Penggunaan Alat Peraga dalam Pengajar Matematika SD. Yogyakarta: PPPG Matematika. juga ikut dirasakan oleh siswa di dalam proses pembelajaran melalui penggunaan media ajar yang telah dikembangkan sebelumnya. Hal ini diharapkan dapat meningkatkan aktivitas belajar, motivasi serta hasil belajar peserta didik.

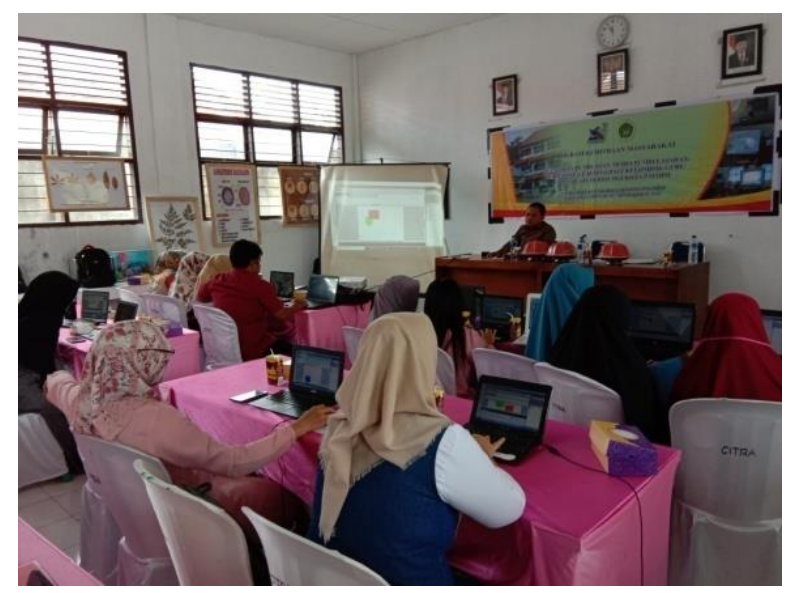

(2)

(2) Pelatiahan Pembuatan Media Berbasis IT

Mertha, I Gde, et al. 2018. Pelatihan Teknik Pembuatan Herbarium Kering dan Identifikasi Tumbuhan Berbasis Lingkungan Sekolah Di SMAN 4 Mataram. Jurnal Pendidikan dan Pengabdian Masyarakat, 1 (1). ISSN: 261-7939.

Islamudin, H. 2012. Psikologi Pendidikan. Yogyakarta: Pustaka Pelajar.

Pangestu, Marta Dwi, Achmad Ali Wafa. 2018. Pengembangan Multimedia Interaktif Powtoon pada Mata Pelajaran Ekonomi Pokok Bahasan Kebijakan Moneter untuk Siswa Kelas XI IPS Di SMA Negeri 1 Singosari. Jurnal Pendidikan Ekonomi, 11 (1). ISSN: 0216-7085.

Rofiyanti, F, Anisa Yunita, S. 2017. Penggunaan Paltform "Kahoot!" dalam Menumbuhkan Jiwa Kompetitif dan Kolaboratif Anak. Pedagagogi: Jurnal Anak Usia Dini dan Pendidikan Anak Usia Dini, 3 (3b). ISSN: 2599-0438.

Rulviana, V. 2018. Implementasi Media Edmodo dalam Mata Kuliah Pengembangan Kurikulum Sekolah Dasar. Jurnal Refleksi Edukatika, 8 (2). ISSN: 20879385. 
MATAPPA: Jurnal Pengabdian Kepada Masyarakat.

Saleh, Husnul Inayah, Nurhayati B, Oslan Jumadi. 2015. Pengaruh Penggunaan Media Alat Peraga Terhadap Hasil Belajar Siswa pada Materi Sistem Peredaran Darah Kelas VIII SMP Negeri 2 Bulukumba. Sainsmat, 4 (1). ISSN: 2086-6755.

Santayasa, I.W. 2007. Landasan Konseptual Media Pembelajaran. Makalah disajikan dalam Workshop Media Pembelajaran Bagi Guru-Guru SMA Negeri Banjar Angkan, di Banjar Angkan Klungkung, 10 Januari 2007.
Saparuddin dan Ekawati. 2017. Analisis Penggunaan Media Pembelajaran di Tingkat Sekolah Menengah Atas/Sederajat Kota Palopo. Biogenerasi, 1 (2). ISSN: 2579-5163. 